Research Article

www.ijrap.net

\title{
ABHRAK BHASMA MEDIATED ALTERATIONS IN LIVER AND KIDNEY FUNCTIONS IN MALE ALBINO RATS DURING CARBON TETRACHLORIDE INDUCED TOXICITY \\ Teli Parashuram ${ }^{1}$, Chougule Priti ${ }^{1}$, Jadhav Jaywant ${ }^{1}$ and Kanase Aruna ${ }^{2} *$ \\ ${ }^{1}$ Cell Biology Section, Department of Zoology, Shivaji University, Kolhapur, Maharashtra, India \\ ${ }^{2}$ APT Research Foundation-National Toxicological Center, Pune, Maharashtra, India
}

Received on: 12/08/13 Revised on: 05/10/13 Accepted on: 10/10/13

\author{
*Corresponding author \\ E-mail: arunakanase@gmail.com \\ DOI: 10.7897/2277-4343.04514 \\ Published by Moksha Publishing House. Website www.mokshaph.com \\ All rights reserved.
}

\section{ABSTRACT}

Abhrak bhasma, an Ayurvedic drug used against many diseases including hepatitis. In present study various doses of abhrak bhasma (10, 20, 30 and $40 \mathrm{mg} / \mathrm{kg}$ body wt) were tested for hepatoprotective efficacy against carbon tetrachloride $\left(\mathrm{CCl}_{4}\right)$ intoxicated liver and kidney functions in male albino rat. Administration of $\mathrm{CCl}_{4}$ to the normal rat increased serum levels of AST, ALT, ALP and bilirubin indicated acute damage. Abhrak bhasma treatment counteracted the action of $\mathrm{CCl}_{4}$ on liver and kidney functions. With the administration of increasing doses of abhrak bhasma all activities were dropped progressively and significantly at $40 \mathrm{mg}$ dose as compared with silicate control. Conjugation metabolism and excretion of bilirubin were improved with increasing doses of abhrak bhasma suggesting dose dependent protection of all metabolic steps in bilirubin metabolism. Also $\mathrm{CCl}_{4}$ induced acute toxicity increased serum urea and creatinine content, which was progressively controlled by increasing abhrak bhasma doses. The findings of this study indicated that abhrak bhasma exert dose dependent protective effects in liver and kidneys functions against $\mathrm{CCl}_{4}$ induced toxicity in albino rat.

Keywords: Abhrak bhasma, Hepatoprotective efficacy, Metabolic steps, Bilirubin metabolism, Creatinine content.

\section{INTRODUCTION}

Liver and kidneys play an essential role in regulating various physiological processes in the body such as metabolism, secretion, detoxification and other biotransformations. Exposure of hazardous or toxic substances affects target organs that increase the stress on liver and kidney. It is suggested that various forms of liver injuries may be caused by free radical formation and subsequent oxidative stress. The reactive oxygen species (ROS), such as hydroxyl radical, superoxide radical anion and nitric oxide may injure cell membranes through lipid peroxidation ${ }^{1}$. It is demonstrated that carbon tetrachloride $\left(\mathrm{CCl}_{4}\right)$ intoxication can cause generation of reactive oxygen species (ROS) in many tissues ${ }^{2,3}$. Free radicals that induce lipid peroxidation cause cell membrane damage leading to a number of pathological changes in acute and chronic renal injuries ${ }^{4,5}$. The protection and cure of liver is obligatory to maintain the health. In Ayurveda many herbs and formulas often have a wide spectrum of therapeutic activity. Many drugs are mentioned to protect liver and kidneys. Liver produces the metabolic wastes urea, which is taken through blood to the kidney for filtration. Similarly, some of the products of drug metabolism also carried through blood for excretion. This may affect the kidney adversely. Kidney is a vital organ that removes waste from the body and hence must be studied for the renal toxicity. It has been reported that the effects of $\mathrm{CCl}_{4}$ on kidney structure and function depends on the functional state of the liver ${ }^{6}$. In present work abhrak bhasma, a commonly used Ayurvedic drug was used to treat $\mathrm{CCl}_{4}$ induced hepatotoxicity in protective experimental schedule in male albino rat. $\mathrm{CCl}_{4}$ induced liver injury in animals has been proved to be highly useful as an experimental model to study the mechanism underlying the hepatotoxic effects, like hepatitis and fibrosis ${ }^{7}$. There are several biochemical tests available to detect toxicity with hepatic and renal dysfunction referred to as functional tests; are evaluated in present study. The toxicity of abhrak bhasma is tested using various doses of abhrak bhasma. Usually modern scientists consider bhasmas as oxides, because they are heated during their preparation, therefore the results are also compared with the silicon dioxide $\left(\mathrm{SiO}_{2}\right)$ treated rat, since Abhrak bhasma is derived from micaore, which is rich in silicates.

\section{MATERIAL AND METHODS \\ Preparation of abhrak bhasma}

Abhrak bhasma was prepared in the laboratory as described in Rasa Ratna Sammucchaya ${ }^{8}$. To study the detailed intermediary effects of abhrak bhasma on liver and kidney functions different doses of abhrak bhasma viz., 10, 20, 30 and $40 \mathrm{mg} / \mathrm{kg}$ body wt were used during present study. The abhrak bhasma was administered with honey. To check this criticism in present project the quartz powder $\left(\mathrm{SiO}_{2}\right)$ i. e. naturally occurring silica dioxide was also tested for its protective efficacy to compare it with abhrak bhasma.

\section{Experimental Animal}

Male albino rats, Rattus norvegicus (Wistar strain) originally derived from National Institute of Virology, Pune, India were bred and maintained in the animal house of the department (Reg. No. 233/CPCSEA). The rats were fed with standard pellet diet (Amrit feeds, Sangli, Maharashtra, India). Male albimo rats, which were 90 days old and weighed 130-140 g each were used for experiments. 
Experimental design for hepatoprotective activity

Animals were randomly assigned into several groups of six each as per various treatments given which are as follows:

- Group I: Normal rats without any treatment.

- Group II: 10 mg Abhrak bhasma / kg body wt/ day for 7 days given orally.

- Group III: $20 \mathrm{mg}$ Abhrak bhasma / kg body wt/ day for 7 days given orally.

- Group IV: 30 mg Abhrak bhasma / kg body wt/ day for 7 days given orally.

- Group V: 40 mg Abhrak bhasma / kg body wt/ day for 7 days given orally.

- Group VI: $10 \mathrm{mg} \mathrm{SiO}_{2} / \mathrm{kg}$ body wt / day for 7 days given orally.

- Group VII: $20 \mathrm{mg} \mathrm{SiO}_{2} / \mathrm{kg}$ body wt / day for 7 days given orally.

- Group VIII: $30 \mathrm{mg} \mathrm{SiO}_{2} / \mathrm{kg}$ body wt / day for 7 days given orally.

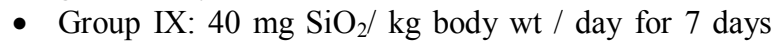
given orally.

- Group X: Acute hepatotoxicity induced by $\mathrm{CCl}_{4}(3.0$ $\mathrm{ml} / \mathrm{kg}$ body weight / day for 7 days subcutaneously).

- Group XI: $\mathrm{CCl}_{4}(3.0 \mathrm{ml} / \mathrm{kg}$ body wt / day for 7 days $)$ + (10 mg abhrak bhasma / kg body wt / day for 7 days, simultaneously).

- Group XII: $\mathrm{CCl}_{4}(3.0 \mathrm{ml} / \mathrm{kg}$ body wt / day for 7 days $)$ + (20 mg Abhrak bhasma / kg body wt of rat / day for 7 days, simultaneously).

- Group XIII: $\mathrm{CCl}_{4}(3.0 \mathrm{ml} / \mathrm{kg}$ body wt / day for 7 days $)$ + (30 mg Abhrak bhasma / kg body wt / day for 7 days, simultaneously).

- Group XIV: $\mathrm{CCl}_{4}(3.0 \mathrm{ml} / \mathrm{kg}$ body wt / day for 7 days) + (40 mg Abhrak bhasma / kg body wt / day for 7 days, simultaneously).

- Group XV: $\mathrm{CCl}_{4}$ (3.0 ml / kg body wt / day for 7 days) $+\left(10 \mathrm{mg} \mathrm{SiO}_{2} / \mathrm{kg}\right.$ body wt / day for 7 days, simultaneously).
- Group XVI: $\mathrm{CCl}_{4}(3.0 \mathrm{ml} / \mathrm{kg}$ body wt / day for 7 days $)+\left(20 \mathrm{mg} \mathrm{SiO}_{2} / \mathrm{kg}\right.$ body wt/ day for 7 days, simultaneously).

- Group XVII: $\mathrm{CCl}_{4}(3.0 \mathrm{ml} / \mathrm{kg}$ body wt/ day for 7 days $)+\left(30 \mathrm{mg} \mathrm{SiO}_{2} / \mathrm{kg}\right.$ body wt / day for 7 days, simultaneously).

- Group XVIII: $\mathrm{CCl}_{4}(3.0 \mathrm{ml} / \mathrm{kg}$ body wt/ day for 7 days $)+\left(40 \mathrm{mg} \mathrm{SiO}_{2} / \mathrm{kg}\right.$ body wt/ day for 7 days, simultaneously).

\section{Determination of Liver and kidney toxicity \\ Collection of serum}

On the completion of the experimental schedule giving deep ether anaesthesia animals were killed. The blood samples were aspirated from the pinna with the disposable syringes and were allowed to clot at room temperature On clotting the serum samples were obtained by centrifuging the clots using tabletop centrifuge.

\section{Determination of liver and kidney functional tests}

Diagnosis of liver function was performed by measuring serum GOT / AST (Aspartate aminotransferase), GPT / ALT (Alanine aminotransferase), Alkaline phosphatase (ALP) and bilirubin (conjugated and non conjugated). While kidney function was diagnosed by measuring serum urea and creatinine. All these biochemical tests were performed by Auto analyzer (Model No. ECOM6124F; Manufactured by EPPENDORF).

\section{Statistical Analysis}

All the results obtained were analyzed statistically. The statistical calculations were carried out with the help of XLSTAT 7.5 computer programme. Statistical significance between groups was analyzed by using I-way ANOVA; fooled by student ' $\mathrm{t}$ ' test. The values of $\mathrm{p}<$ $0.05, \mathrm{p}<0.01, \mathrm{p}<0.001$ were considered as significant.

Table 1: Abhrak bhasma mediated alterations in serum AST and ALT and ALP levels in $\mathrm{CCl}_{4}$ intoxicated male albino rats protective

\begin{tabular}{|c|c|c|c|c|}
\hline S. No. & Group & AST & ALT & ALP \\
\hline 1 & Normal & $20.18 \pm 1.19$ & $15.27 \pm 0.83$ & $28.43 \pm 1.65$ \\
\hline 2 & $\mathrm{CCl}_{4}(3.0 \mathrm{ml} / \mathrm{kg}$ body $\mathrm{wt}) \mathrm{sc}$ & $107.36 \pm 5.54^{\mathrm{c}}$ & $99.30 \pm 5.06^{\mathrm{c}}$ & $66.08 \pm 3.61^{\mathrm{c}}$ \\
\hline 3 & $\mathrm{CCl}_{4}+$ Abhrak bhasma (10 mg/kg body wt) & $70.43 \pm 3.87^{\mathrm{c}, z}$ & $61.42 \pm 3.36^{\mathrm{c}, \mathrm{z}}$ & $58.13 \pm 3.4^{\mathrm{c}}$ \\
\hline 4 & $\mathrm{CCl}_{4}+\mathrm{Abhrak}$ bhasma $(20 \mathrm{mg} / \mathrm{kg}$ body wt $)$ & $64.38 \pm 3.45^{\mathrm{c}, \mathrm{z}}$ & $59.28 \pm 3.71^{\mathrm{c}, \mathrm{z}}$ & $45.42 \pm 2.69^{\mathrm{c}, \mathrm{z}}$ \\
\hline 5 & $\mathrm{CCl}_{4}+$ Abhrak bhasma $(30 \mathrm{mg} / \mathrm{kg}$ body wt) & $41.02 \pm 2.52^{\mathrm{c}, \mathrm{z}}$ & $48.72 \pm 2.52^{\mathrm{c}, \mathrm{z}}$ & $37.78 \pm 2.17^{\mathrm{c}, \mathrm{z}}$ \\
\hline 6 & $\mathrm{CCl}_{4}+$ Abhrak bhasma (40 mg/kg body wt) & $25.13 \pm 1.49^{\mathrm{a}, \mathrm{z}}$ & $26.68 \pm 1.49^{\mathrm{c}, z}$ & $30.11 \pm 1.64^{z}$ \\
\hline 7 & $\mathrm{CCl}_{4}+\mathrm{SiO}_{2}(10 \mathrm{mg} / \mathrm{kg}$ body $\mathrm{wt})$ & $75.12 \pm 4.89^{\mathrm{c}, \mathrm{y}}$ & $65.37 \pm 4.03^{\mathrm{c}, \mathrm{y}}$ & $60.13 \pm 3.43^{c}$ \\
\hline 8 & $\mathrm{CCl}_{4}+\mathrm{SiO}_{2}(20 \mathrm{mg} / \mathrm{kg}$ body wt $)$ & $80.23 \pm 4.46^{\mathrm{c}, \mathrm{y}}$ & $102.21 \pm 5.48^{\mathrm{c}}$ & $55.37 \pm 3.16^{\mathrm{c}, \mathrm{x}}$ \\
\hline 9 & $\mathrm{CCl}_{4}+\mathrm{SiO}_{2}(30 \mathrm{mg} / \mathrm{kg}$ body wt $)$ & $91.17 \pm 4.73^{\mathrm{c}, \mathrm{x}}$ & $94.48 \pm 5.49^{\mathrm{c}}$ & $52.84 \pm 2.96^{\mathrm{c}, \mathrm{x}}$ \\
\hline 10 & $\mathrm{CCl}_{4}+\mathrm{SiO}_{2}(40 \mathrm{mg} / \mathrm{kg}$ body wt $)$ & $68.19 \pm 3.71^{\mathrm{c}, \mathrm{z}}$ & $59.11 \pm 3.64^{\mathrm{c}, \mathrm{z}}$ & $40.55 \pm 2.27^{\mathrm{c}, \mathrm{z}}$ \\
\hline 11 & Abhrak bhasma ( $10 \mathrm{mg} / \mathrm{kg}$ body wt) & $20.43 \pm 1.26^{z}$ & $11.16 \pm 0.64^{\mathrm{bz}}$ & $23.21 \pm 1.34^{\mathrm{az}}$ \\
\hline 12 & Abhrak bhasma ( $20 \mathrm{mg} / \mathrm{kg}$ body wt) & $24.38 \pm 1.53^{\mathrm{Z}}$ & $19.92 \pm 1.09^{\mathrm{bz}}$ & $24.22 \pm 1.49^{z}$ \\
\hline 13 & Abhrak bhasma( $30 \mathrm{mg} / \mathrm{kg}$ body wt) & $21.02 \pm 1.29^{z}$ & $18.58 \pm 1.06^{\mathrm{az}}$ & $26.02 \pm 1.54^{z}$ \\
\hline 14 & Abhrak bhasma ( $40 \mathrm{mg} / \mathrm{kg}$ body wt) & $25.39 \pm 1.42^{\mathrm{a}}$ & $16.23 \pm 0.91^{\mathrm{z}}$ & $25.79 \pm 1.53^{\mathrm{z}}$ \\
\hline 15 & $\mathrm{SiO}_{2}(10 \mathrm{mg} / \mathrm{kg}$ body wt $)$ & $25.52 \pm 1.48^{\mathrm{a}}$ & $25.42 \pm 1.44^{\mathrm{cz}}$ & $28.34 \pm 1.75^{z}$ \\
\hline 16 & $\mathrm{SiO}_{2}(20 \mathrm{mg} / \mathrm{kg}$ body $\mathrm{wt})$ & $30.05 \pm 2.46^{b}$ & $20.21 \pm 1.00^{\mathrm{bz}}$ & $27.82 \pm 1.70^{z}$ \\
\hline 17 & $\mathrm{SiO}_{2}(30 \mathrm{mg} / \mathrm{kg}$ body wt $)$ & $31.25 \pm 2.73^{\mathrm{b}}$ & $24.18 \pm 1.35^{\mathrm{cz}}$ & $29.34 \pm 1.82^{z}$ \\
\hline 18 & $\mathrm{SiO}_{2}(40 \mathrm{mg} / \mathrm{kg}$ body $\mathrm{wt})$ & $38.13 \pm 2.11^{\mathrm{c}}$ & $29.35 \pm 1.67^{\mathrm{cz}}$ & $22.17 \pm 1.29^{\mathrm{a}}$ \\
\hline
\end{tabular}

Values expressed as units $/ \mathrm{ml}$ serum); Values are mean \pm SE of 6 animals; $\mathrm{p}$-values $-\mathrm{a}<0.05, \mathrm{~b}<0.01$ and $\mathrm{c}<0.001$ vs. normal rat; $\mathrm{x}<0.05, \mathrm{y}<0.01$ and $\mathrm{z}<0.001$ vs. $\mathrm{CCl}_{4}$ treated rat 
Table 2: Abhrak bhasma mediated changes in serum bilirubin levels in $\mathrm{CCl}_{4}$ intoxicated male albino rats during protective schedule

\begin{tabular}{|c|c|c|c|c|}
\hline S. No. & Group & Conjugated & Unconjugated & Total \\
\hline 1 & Normal & $0.23 \pm 0.013$ & $0.09 \pm 0.005$ & $0.32 \pm 0.02$ \\
\hline 2 & $\mathrm{CCl}_{4}(3.0 \mathrm{ml} / \mathrm{kg}$ body wt $) \mathrm{sc}$ & $0.45 \pm 0.025^{\mathrm{c}}$ & $0.18 \pm 0.010^{c}$ & $0.63 \pm 0.04^{\mathrm{c}}$ \\
\hline 3 & $\mathrm{CCl}_{4}+$ Abhrak bhasma $(10 \mathrm{mg} / \mathrm{kg}$ body wt $)$ & $0.36 \pm 0.021^{\mathrm{c}, \mathrm{x}}$ & $0.15 \pm 0.009^{\mathrm{c}, \mathrm{x}}$ & $0.51 \pm 0.03^{\mathrm{c}, \mathrm{x}}$ \\
\hline 4 & $\mathrm{CCl}_{4}+$ Abhrak bhasma $(20 \mathrm{mg} / \mathrm{kg}$ body wt $)$ & $0.30 \pm 0.017^{\mathrm{b}, \mathrm{z}}$ & $0.17 \pm 0.01^{\mathrm{c}}$ & $0.47 \pm 0.03^{\mathrm{b}, \mathrm{y}}$ \\
\hline 5 & $\mathrm{CCl}_{4}+$ Abhrak bhasma $(30 \mathrm{mg} / \mathrm{kg}$ body wt $)$ & $0.25 \pm 0.014^{z}$ & $0.10 \pm 0.006^{z}$ & $0.35 \pm 0.02^{\mathrm{z}}$ \\
\hline 6 & $\mathrm{CCl}_{4}+$ Abhrak bhasma $(40 \mathrm{mg} / \mathrm{kg}$ body wt $)$ & $0.20 \pm 0.01^{z}$ & $0.08 \pm 0.008^{2}$ & $0.28 \pm 0.01^{z}$ \\
\hline 7 & $\mathrm{CCl}_{4}+\mathrm{SiO}_{2}(10 \mathrm{mg} / \mathrm{kg}$ body wt $)$ & $0.48 \pm 0.027^{\mathrm{c}}$ & $0.20 \pm 0.010^{\mathrm{c}}$ & $0.68 \pm 0.04^{\mathrm{c}}$ \\
\hline 8 & $\mathrm{CCl}_{4}+\mathrm{SiO}_{2}(20 \mathrm{mg} / \mathrm{kg}$ body $\mathrm{wt})$ & $0.35 \pm 0.02^{\mathrm{c}, \mathrm{x}}$ & $0.19 \pm 0.010^{\mathrm{c}}$ & $0.54 \pm 0.04^{\mathrm{c}}$ \\
\hline 9 & $\mathrm{CCl}_{4}+\mathrm{SiO}_{2}(30 \mathrm{mg} / \mathrm{kg}$ body wt $)$ & $0.30 \pm 0.018^{b, z}$ & $0.15 \pm 0.009^{\mathrm{c}, \mathrm{x}}$ & $0.45 \pm 0.03^{\mathrm{b}, \mathrm{z}}$ \\
\hline 10 & $\mathrm{CCl}_{4}+\mathrm{SiO}_{2}(40 \mathrm{mg} / \mathrm{kg}$ body wt $)$ & $0.28 \pm 0.014^{\mathrm{a}, \mathrm{z}}$ & $0.12 \pm 0.007^{\mathrm{b}, \mathrm{y}}$ & $0.40 \pm 0.02^{\mathrm{a}, \mathrm{z}}$ \\
\hline 11 & Abhrak bhasma $(10 \mathrm{mg} / \mathrm{kg}$ body $\mathrm{wt})$ & $0.23 \pm 0.013^{\mathrm{z}}$ & $0.05 \pm 0.008^{\mathrm{b}, \mathrm{z}}$ & $0.28 \pm 0.015^{z}$ \\
\hline 12 & Abhrak bhasma ( $20 \mathrm{mg} / \mathrm{kg}$ body wt) & $0.25 \pm 0.014^{\mathrm{z}}$ & $0.06 \pm 0.005^{\mathrm{z}}$ & $0.31 \pm 0.020^{\mathrm{z}}$ \\
\hline 13 & Abhrak bhasma $(30 \mathrm{mg} / \mathrm{kg}$ body $\mathrm{wt})$ & $0.22 \pm 0.013^{\mathrm{z}}$ & $0.04 \pm 0.002 \mathrm{cz}$ & $0.26 \pm 0.016^{\mathrm{a}, \mathrm{z}}$ \\
\hline 14 & Abhrak bhasma ( $40 \mathrm{mg} / \mathrm{kg}$ body $\mathrm{wt})$ & $0.25 \pm 0.013^{\mathrm{Z}}$ & $0.07 \pm 0.005^{\mathrm{b}, \mathrm{z}}$ & $0.32 \pm 0.018^{\mathrm{z}}$ \\
\hline 15 & $\mathrm{SiO}_{2}(10 \mathrm{mg} / \mathrm{kg}$ body $\mathrm{wt})$ & $0.19 \pm 0.011^{\mathrm{az}}$ & $0.07 \pm 0.005^{\mathrm{b}, \mathrm{z}}$ & $0.26 \pm 0.013^{\mathrm{az}}$ \\
\hline 16 & $\mathrm{SiO}_{2}(20 \mathrm{mg} / \mathrm{kg}$ body wt $)$ & $0.16 \pm 0.08^{y}$ & $0.08 \pm 0.005^{2}$ & $0.24 \pm 0.015^{\mathrm{az}}$ \\
\hline 17 & $\mathrm{SiO}_{2}(30 \mathrm{mg} / \mathrm{kg}$ body $\mathrm{wt})$ & $0.18 \pm 0.09^{x}$ & $0.09 \pm 0.006^{2}$ & $0.27 \pm 0.018^{z}$ \\
\hline 18 & $\mathrm{SiO}_{2}(40 \mathrm{mg} / \mathrm{kg}$ body wt $)$ & $0.19 \pm 0.010^{\mathrm{az}}$ & $0.08 \pm 0.006^{2}$ & $0.27 \pm 0.018^{\mathrm{z}}$ \\
\hline
\end{tabular}

Values are expressed as mg/dl serum; Values are mean \pm SE of 6 animals; $\mathrm{p}$-values $-\mathrm{a}<0.05, \mathrm{~b}<0.01$ and $\mathrm{c}<0.001$ vs. normal rat; $\mathrm{x}<0.05, \mathrm{y}<0.01$ and $\mathrm{z}<0.001$ vs. $\mathrm{CCl}_{4}$ treated rat

Table 3: Abhrak bhasma mediated alterations in serum Urea and Creatinine content in $\mathbf{C C l}_{4}$ intoxicated male albino rats protective schedule

\begin{tabular}{|c|c|c|c|}
\hline S. No. & Group & Urea & Creatinine \\
\hline 1 & Normal & $17.25 \pm 1.06$ & $3.24 \pm 0.18$ \\
\hline 2 & $\mathrm{CCl}_{4}(3.0 \mathrm{ml} / \mathrm{kg}$ body wt $) \mathrm{sc}$ & $55.03 \pm 3.18^{\mathrm{c}}$ & $8.27 \pm 0.51^{\mathrm{c}}$ \\
\hline 3 & $\mathrm{CCl}_{4}+$ Abhrak bhasma $(10 \mathrm{mg} / \mathrm{kg}$ body wt $)$ & $35.6 \pm 2.05^{\mathrm{c}, \mathrm{z}}$ & $6.55 \pm 0.39^{\mathrm{c}, \mathrm{x}}$ \\
\hline 4 & $\mathrm{CCl}_{4}+$ Abhrak bhasma $(20 \mathrm{mg} / \mathrm{kg}$ body wt $)$ & $23.91 \pm 1.38^{\mathrm{b}, \mathrm{z}}$ & $4.39 \pm 0.25^{\mathrm{b}, \mathrm{z}}$ \\
\hline 5 & $\mathrm{CCl}_{4}+$ Abhrak bhasma $(30 \mathrm{mg} / \mathrm{kg}$ body wt $)$ & $22.38 \pm 1.28^{\mathrm{a}, \mathrm{z}}$ & $3.78 \pm 0.23^{2}$ \\
\hline 6 & $\mathrm{CCl}_{4}+$ Abhrak bhasma $(40 \mathrm{mg} / \mathrm{kg}$ body wt) & $19.26 \pm 1.25^{z}$ & $3.10 \pm 0.18^{z}$ \\
\hline 7 & $\mathrm{CCl}_{4}+\mathrm{SiO}_{2}(10 \mathrm{mg} / \mathrm{kg}$ body wt $)$ & $48.54 \pm 3.10^{c}$ & $4.43 \pm 2.84$ \\
\hline 8 & $\mathrm{CCl}_{4}+\mathrm{SiO}_{2}(20 \mathrm{mg} / \mathrm{kg}$ body wt $)$ & $32.24 \pm 1.92^{\mathrm{c}, \mathrm{z}}$ & $6.28 \pm 0.36^{\mathrm{c}, \mathrm{y}}$ \\
\hline 9 & $\mathrm{CCl}_{4}+\mathrm{SiO}_{2}(30 \mathrm{mg} / \mathrm{kg}$ body wt $)$ & $30.41 \pm 1.80^{\mathrm{c}, \mathrm{z}}$ & $5.94 \pm 0.37^{\mathrm{c}, y}$ \\
\hline 10 & $\mathrm{CCl}_{4}+\mathrm{SiO}_{2}(40 \mathrm{mg} / \mathrm{kg}$ body wt $)$ & $21.32 \pm 1.31^{\mathrm{a}, \mathrm{z}}$ & $3.67 \pm 0.22^{\mathrm{z}}$ \\
\hline 11 & Abhrak bhasma ( $10 \mathrm{mg} / \mathrm{kg}$ body $\mathrm{wt})$ & $25.6 \pm 1.56^{\mathrm{b}, \mathrm{z}}$ & $3.11 \pm 0.19^{\mathrm{z}}$ \\
\hline 12 & Abhrak bhasma ( $20 \mathrm{mg} / \mathrm{kg}$ body wt) & $23.91 \pm 1.51^{\mathrm{b}, \mathrm{z}}$ & $3.58 \pm 0.20^{z}$ \\
\hline 13 & Abhrak bhasma( $30 \mathrm{mg} / \mathrm{kg}$ body wt) & $22.38 \pm 1.22^{\mathrm{b}, \mathrm{z}}$ & $3.85 \pm 0.22^{z}$ \\
\hline 14 & Abhrak bhasma (40 mg/kg body wt) & $19.26 \pm 1.11^{z}$ & $3.41 \pm 0.18^{z}$ \\
\hline 15 & $\mathrm{SiO}_{2}(10 \mathrm{mg} / \mathrm{kg}$ body wt $)$ & $25.36 \pm 1.56^{b, z}$ & $3.94 \pm 0.20^{\mathrm{a}, \mathrm{z}}$ \\
\hline 16 & $\mathrm{SiO}_{2}(20 \mathrm{mg} / \mathrm{kg}$ body wt $)$ & $21.69 \pm 1.29^{\mathrm{a}, \mathrm{z}}$ & $4.01 \pm 0.23^{\mathrm{a}, \mathrm{z}}$ \\
\hline 17 & $\mathrm{SiO}_{2}(30 \mathrm{mg} / \mathrm{kg}$ body wt $)$ & $26.56 \pm 1.52^{\mathrm{c}, \mathrm{z}}$ & $3.78 \pm 0.21^{\mathrm{z}}$ \\
\hline 18 & $\mathrm{SiO}_{2}(40 \mathrm{mg} / \mathrm{kg}$ body wt $)$ & $29.35 \pm 1.79^{\mathrm{c}, \mathrm{z}}$ & $3.52 \pm 0.22^{2}$ \\
\hline
\end{tabular}

Values expressed as $\mathrm{mg} / \mathrm{dl}$ serum; Values are mean $\pm \mathrm{SE}$ of 6 animals. $\mathrm{p}$-values $-\mathrm{a}<0.05, \mathrm{~b}<0.01$ and $\mathrm{c}<0.001$ vs. normal rat; $\mathrm{x}<0.05, \mathrm{y}<0.01$ and $\mathrm{z}<0.001$ vs. $\mathrm{CCl}_{4}$ treated rat

\section{RESULTS AND DISCUSSION}

This study was undertaken to demonstrate the protective activity of various doses of abhrak bhasma on liver and kidney functions in $\mathrm{CCl}_{4}$ intoxicated male albino rat. The mechanism of $\mathrm{CCl}_{4}$-induced liver and kidney injury is well documented in the rat model ${ }^{9-11}$. The damage of the liver caused by $\mathrm{CCl}_{4}$ was evident by the alterations in serum marker enzyme concentrations beside the clinical signs and histopathology. In our study $\mathrm{CCl}_{4}$ induced liver and kidney damage was represented by significant elevation of serum and urine markers (AST, ALT, ALP, total bilirubin, Urea and creatinine). Administration of $\mathrm{CCl}_{4}$ (seven doses, $3.0 \mathrm{ml} / \mathrm{kg}$ body wt / day) to normal rat increased serum levels of AST, ALT, ALP and bilirubin and confirmed the earlier results. Both AST and ALT activities were increased on $\mathrm{CCl}_{4}$ administration indicate that by acute damage, AST and ALT activities are not cleared rapidly and thus are retained in circulation due to continued stress on liver and possibly on other organs since kidney is known to be under stress ${ }^{12}$. It is well established that the toxic metabolite of $\mathrm{CCl}_{4}$, a free radical $\mathrm{CCl}_{3}$ is responsible for damage to liver cells. With the administration of 10 and $20 \mathrm{mg}$ doses of abhrak bhasma, about $40 \%$ of the AST and ALT activities were dropped while differences in the activities dropped by 10 $\mathrm{mg}$ and $20 \mathrm{mg}$ dose were not significant. While drop observed with $30 \mathrm{mg}$ and $40 \mathrm{mg}$ dose was linearly progressive and was marginally high as compared to normal activities of ALT and AST. The control drug, silicate used to evaluate the abhrak bhasma showed different influence on liver and kidney functions. Though initial drop with $10 \mathrm{mg}$ dose was $30.03 \%$ and $34.17 \%$ in case of AST and ALT activities respectively; further 20 $\mathrm{mg}$ and $30 \mathrm{mg}$ doses increased the enzymes activities as compared to $10 \mathrm{mg}$ dose, but ALT activity was further increased by $20 \mathrm{mg}$ dose and dropped marginally with 30 $\mathrm{mg}$ dose. $40 \mathrm{mg}$ dose dropped the activities of both the enzymes as compared to $30 \mathrm{mg}$ dose treatment (Table 1). The pattern of alterations in ALP activities by abhrak bhasma indicated dose dependent progressive lowering of the activities, which remained notably high over normal activities indicating stress on liver and kidney. However the drop in ALP activities was observed with the $10 \mathrm{mg}$ dose of silicates and further dose dependent loss in 
activity noted were progressively lowering, but with very narrow range and remained high than normal activity significantly. The results indicated that as compared to silicates the Ayurvedic preparation abhrak bhasma is more potent. Similarly, abhrak bhasma showed dose dependent progressive improvement in liver functioning as illustrated by alterations in AST and ALT activities, but that was not observed with the silicates where lowering of the activities of enzymes were noted nonspecific to dose. Abhrak bhasma at $40 \mathrm{mg}$ dose showed stress, which may be due to the protective activities and assaulting activities are simultaneously progressive in liver. In spite of the stress significant protection of liver functions observed with $40 \mathrm{mg}$ dose. This was not true with the silicate treatment, where more significant response was observed with $10 \mathrm{mg}$ dose also showed significant drop in the activities. However at $20 \mathrm{mg}$ and $30 \mathrm{mg}$ doses drop was comparatively at low level in AST and ALT and was nearly as observed in $\mathrm{CCl}_{4}$ treatment. In case of ALP activities linear drop related to doses was observed, which was true in case of both $\mathrm{CCl}_{4}$ abhrak bhasma treated and $\mathrm{CCl}_{4}+$ silica treated rats. These results indicate that no variations were occurred in ALP activities with the $\mathrm{CCl}_{4}+$ abhrak bhasma treated rat and $\mathrm{CCl}_{4}+$ silicate treated rats in the pattern of alterations. It may be because alkaline phosphates released due to $\mathrm{CCl}_{4}$ was controlled by abhrak bhasma and may be not involving more complex interdependent reactions and managed by $40 \mathrm{mg}$ dose of abhrak bhasma. While silicate may be influencing similar way since activities are lowered dose dependently but not potently indicating protection of ALP activities was not lowered totally still it has the potency to lower ALP activities in serum irrespective of organ from which they are generated. The increased levels of conjugated and unconjugated bilirubin were nearly in equal indicating the alterations in excretion of bilirubins so also the impairment of conjugation metabolism. Bilirubin is taken up from blood into hepatocytes by sinusoidal membrane transporters and then excreted into bile through the bile canalicular membrane mainly as bilirubin glucuronides ${ }^{13,14}$. Bilirubin is uptaken into hepatocytes by organic anion transporting polypeptides (rat, Oatp1, Oatp2, Oatp3, human Oatp), liver specific transporter (Vist/HLST), and /or by OAT2, OAT3, since unconjugated levels in plasma are increased by $\mathrm{CCl}_{4}$, it is possible that the necrotic hepatocytes may have altered their membrane and are unable to intake the un conjugated bilirubin. It may be true in case of sinusoidal cells in necrotic region. This may have caused the increase in unconjugated bilirubin. Since the intra hepatic transporters and conjugation in bilirubin: legand in carriers bilirubin to the endoplasmic reticulum (ER) of hepatocytes, where it is conjugated by bilirubin uridin diphosphate (UDP)-glycosyl transferase to form mono and diglucuronides of bilirubin ${ }^{15}$, which are excreted into bile by multidrug resistance- associated protein 2 (MRP2)- a membrane of ATP-binding cassette transporter family ${ }^{16}$. The depletion in ligandin protein may impair this process and may participate in the increase of unconjugated bilirubin. In present results liver total proteins were reduced and possibly ligandin, which is inducible protein ${ }^{17}$ and decrease in its concentration may lead to increase in plasma unconjugated proteins. As centrolobular necrosis is due to fatty degeneration, which is caused due to ER destruction in hepatocytes ${ }^{18,19}$. The process will also lead to no conjugation of bilirubin and hence the unconjugated bilirubin from hepatocyte may have diffused to the plasma, as the process of diffusion of bilirubin is known ${ }^{20,21}$. Thus leading to high levels of unconjugated bilirubin in plasma. Regurgitation of bilirubin glucuronides into blood: MRP3, which is located in the lateral membrane and is known to transport bilirubin glucuronides into blood under the conditions of impaired biliary bilirubin excretion. In present conditions $\mathrm{CCl}_{4}$ induced centrolobular necrosis had already blocked the bile canaliculi and hence conjugated bilirubin may have found its way in plasma by regurgitation. Since both conjugated and unconjugated bilirubin has increased by similar folds, both the metabolisms that are uptake of plasma unconjugated bilirubin and its further processing up to conjugate form and conjugation and bilirubins and also the excretion of conjugated forms must have been interrupted by $\mathrm{CCl}_{4}$ induced toxicity. Abhrak bhasma mediated dose dependent depletion in un conjugated bilirubin content reveals that the improvement at the levels of uptake of un conjugated bilirubins from plasma by hepatocytes and sinusoidal cells. The marginal high levels by $20 \mathrm{mg}$ may be due to availability of the different proteins including ligandin. It seems to have influenced the ligandin: bilirubin binding, since ligandin binding and other anion transporters which are known to be involved in the process. The parallax between ligandin synthesis and bilirubin binding up to saturation lead to transport in ER which may had some delay and hence the increase in plasma unconjugated bilirubin may have been observed. The process of conjugation of bilirubin and its excretion seems to be dose dependent. $\mathrm{SiO}_{2}$ treatment at $10 \mathrm{mg}$ dose had increased conjugated bilirubin over $\mathrm{CCl}_{4}$ treated rat indicating no influence of low dose, but further doses seems to have improved the conjugation and excretion of bilirubin though not fully with $40 \mathrm{mg}$ dose. With 10 and $20 \mathrm{mg}$ doses of $\mathrm{SiO}_{2}$ had not increased the unconjugated bilirubin marginally while 30 and $40 \mathrm{mg}$ had reduced unconjugated bilirubin in plasma considerably, though not its content is normalized (Table 2). Since $\mathrm{SiO}_{2}$ is anion, it may be influencing the transport of unconjugated, as conjugated bilirubin in and out of hepatocytes as organic anion transporters are playing role in the transport of bilirubins so the role of $\mathrm{SiO}_{2}$ into this transport can't be excluded. Thus the result of plasma content indicates that abhrak bhasma protects bilirubin transport from plasma to hepatocytes, its conjugation and excretion dose dependent and $40 \mathrm{mg}$ dose showing total protection. But $\mathrm{SiO}_{2}$ does not protect all these metabolic steps in bilirubin metabolism fully but it protects these metabolisms with low potency. Administration of $\mathrm{CCl}_{4}$ to the normal rats increased the urea and creatinine contents in plasma and confirmed earlier results. Increase in folds of creatinine indicating the stress on clearance. The results also showed that area damaged by $\mathrm{CCl}_{4}$ was centrolobular area that had not influenced the urea synthesis since periarterial remained unaffected the rate of production of urea is not influenced as hepatocytes of this region produce urea. Dose dependent improvement in urea clearance was 
observed in $\mathrm{CCl}_{4}+$ abhrak bhasma treated rats. These results can be related with the improvement in foggy areas of kidney. The creatinine clearance was also improved linearly with increasing doses of abhrak bhasma with 10 and $40 \mathrm{mg}$ of dose which marginally lowered than the normal indicating improvement in creatinine clearance by $40 \mathrm{mg}$ dose of abhrak bhasma in $\mathrm{CCl}_{4}$ treated rats. However, in silicate treatments though plasma urea clearance is dose dependent it is not significantly different with $20 \mathrm{mg}$ and $30 \mathrm{mg}$ doses, but deplete was significant with $10 \mathrm{mg}$ and $20 \mathrm{mg}$ doses while with $40 \mathrm{mg}$ doses the urea levels remained high. $\mathrm{CCl}_{4}$ induced acute hepatotoxicity increased serum creatinine content, which was progressively reduced by increasing abhrak bhasma doses (Table 3). With $40 \mathrm{mg}$ dose the creatinine levels were marginally below the normal levels. These results indicated the abhrak bhasma clearance through glomerulus, as serum levels were depleted. Since creatinine is widely used to estimate glomerular function, silicate treatments resulted depletion of creatinine by all doses of $\mathrm{SiO}_{2}$. Thus silicates as abhrak bhasma lowers the plasma urea and creatinine content and $10 \mathrm{mg}$ being more creatinine production influenced since silicates are known to influence muscle fibroblasts but high dose brought the protection slowly except $40 \mathrm{mg}$ dose. Thus, the results indicate that abhrak bhasma has controlled both urea and creatinine levels in plasma. In conclusion, results of the present study indicated that in the present experimental conditions, abhrak bhasma exert dose dependent protective effects in liver and kidneys functions against $\mathrm{CCl}_{4}$ induced toxicity in albino rat. However, further detailed studies are required to establish its proper treatment in liver and kidney damage induced by oxidative stress.

\section{ACKNOWLEDGMENTS}

Authors are sincerely thankful to Dr. Shriram M. Soman, Shriseva Pathology Laboratory, Rajarampuri, Kolhapur, India for excellent technical assistance during conducting the study.

\section{REFERENCES}

1. Valko M, Leibfritz D, Moncol J, Cronin MT, Mazur M, Telser J. Free radicals and antioxidants in normal physiological functions and human disease. Int. J. Biochem. Cell. Biol 2007; 39: 44-84. http:// dx.doi.org/10.1016/j.biocel.2006.07.001 PMid:16978905

2. Rechnagel RO, Glende EA, Dolak JA, Waller RL. Mechanisms of carbon tetrachloride toxicity. J Pharmacol Exp Ther 1989; 43: 13954. http://dx.doi.org/10.1016/0163-7258(89)90050-8

3. Khan MR, Ahmed D. Protective effects of Digera muricata (L.) Mart. on testis against oxidative stress of carbon tetrachloride in rat. Food Chem Toxicol 2009; 47: 1393-1399. http://dx.doi.org/10.1016 /j.fct.2009.03.020 PMid:19327381

4. Khan MR, Rizvi W, Khan GN, Khan RA, Shaheen S. Carbon tetrachloride-induced nephrotoxicity in rats: protective role of Digera muricata. Journal of Ethno pharmacology 2009; 122(1): 9199. http://dx.doi.org/10.1016/j.jep.2008.12.006 PMid:19118616

5. Khan RA, Khan MR, Sahreen S, Bokhari J. Prevention of $\mathrm{CCl}_{4}$ induced nephrotoxicity with Sonchus asper in rat. Food and Chemical Toxicology 2010; 48(8-9): 2469-2476. http://dx.doi.org /10.1016/j.fct.2010.06.016 PMid:20550952
6. Rincon AR, Covarrubias A, Pedraza Chaverri J, Poo JL, Armendariz Borunda J, Panduro A. Differential effect of $\mathrm{CCl}_{4}$ on renal function in cirrhotic and non-cirrhotic rats. Exp Toxicol Pathol 1999; 51: 199-205. http://dx.doi.org/10.1016/S0940-2993(99)800 94-3

7. Weber LW, Boll M, and Stampfl A. Hepatotoxicity and mechanism of action of haloalkanes: carbon tetrachloride as a toxicological model. Crit Rev Toxicol 2003; 33(2): 105-36. http://dx.doi.org /10.1080/713611034 PMid:12708612

8. Sharma S. Rasa Ratna Samuchhaya, Published by Motilal Banrasidas, New Delhi; 1977. p. 72-108.

9. Buwa SK. Hepatoprotective and curative effects of abhrak bhasma on liver, kidney and adipose tissue of male albino rats. A Ph. D, thesis submitted to Shivaji University, Kolhapur; 2000.

10. Abraham P, Wilfred G, Cathrine SP. Oxidative damage to the lipids and proteins of the lungs, testis and kidney of rats during carbon tetrachloride intoxication. Clin Chim Acta 1999; 289: 177-179. http://dx.doi.org/10.1016/S0009-8981(99)00140-0

11. Bahcecioglu IH, Ustundag B, Ozercan I. Protective effect of Ginkgo biloba extract on $\mathrm{CCI}_{4}$-induced liver damage. Hepatol Res 1999; 15: 215-224. http://dx.doi.org/10.1016/S1386-6346(99)00029-7

12. Kanase RN. Effects of Ayurvedic drugs on the lysosomal enzymes of liver and kidney after $\mathrm{CCl}_{4}$ induced injury in albino rats. $\mathrm{A} \mathrm{Ph} . \mathrm{D}$ thesis submitted to Shivaji University, Kolhapur; 1998.

13. Stollman YR, Gartner U, Theilmann L, Ohmi N, Wolkoff AW. Hepatic bilirubin uptake in the isolated perfused rat liver is not facilitated by albumen binding. J. Clin. Invest 1983; 72(2): 718-723. http://dx.doi.org/10.1172/JCI111021 PMid:6308060 PMCid:PMC 1129231

14. Fevery J. Bilirubin in clinical practice: a review. Liver International; 2008. p. 592-605. http://dx.doi.org/10.1111/j.1478-3231 2008.01716.x PMid: 18433389

15. Wolkoff AW. Hepatocellular, sinusoidal membrane organic ion transport and transpoters. Semin Liver Dis 1966; 16(12): 121-127.

16. Jacquemin E, Hagenbuch B, Stiger B, Wolkoff AW, Meier PJ. Expression cloning of a rat liver $\mathrm{Na}^{(+)}$-dependent organic anion transporter. Proc. Natl. Acad. Sci USA 1994; 91: 133-137. http://dx. doi.org/10.1073/pnas.91.1.133

17. Kamisaka K, Listowsky I. Arias IM. Circular dichroism studies of $\mathrm{Y}$ protein (ligandin), a major organic anion binding protein in liver, kidney and small intestine. Annals of the New York Acad. of Sciences 1973; 226: 148-153. http://dx.doi.org/10.1111/j.17496632.1973.tb20477.x PMid:4520392

18. Slater TF. Lysosomes and experimentally induced tissue injury, in Lysosomes in Biology and Pathology, vol. I Ed. by J T Dingle and H B Fell. Published by North Holland Publishing Company, Amsterdam; 1969. p. 467-488.

19. Mehendale HM. Hepatic toxicity, in Modern Toxicology Vol. I. Ed. By Gupta BV and Salunkhe DK, Pub. By MD Metropolian Book Co Pvt Ltd N.S. Marg, New Delhi 110002, India; 1985.

20. Torres AM, Lunazzi GC, Stremmel W, Tiribelli C. Bilitranslocase and sulfobromophthalein / bilirubib- binding protein are both involved in the hepatic uptake of organic anions. Proc. of National Acad. of Sci. of the USA 1993; 90(17): 8136-8139. http://dx. doi.org/10.1073/pnas.90.17.8136

21. Zucker SD, Goessling W, Hoppin AG. Unconjugated bilirubin exhibits spontaneous diffusion through model lipid bi layers and native hepatocyte membranes. Journal of Biol. Chemistry 1999; 274: 10852-10862. http://dx.doi.org/10.1074/jbc.274.16.10852 PMid:10196162

\section{Cite this article as:}

Teli Parashuram, Chougule Priti, Jadhav Jaywant and Kanase Aruna. Abhrak bhasma mediated alterations in liver and kidney functions in male albino rats during carbon tetrachloride induced toxicity. Int. J. Res. Ayurveda Pharm. 2013;4(5):696-700 http://dx.doi.org/10.7897/2277$\underline{4343.04514}$ 